\title{
TEORI RASIONALITAS MENURUT EKONOMI ISLAM
}

\author{
Herlan Firmansyah
}

\begin{abstract}
Abstrak (Abstact)
Pandangan tentang konsep rasionalitas memiliki konsekuensi terhadap perilaku manusia dalam melakukan tindakan ekonomi dan tujuan-tujuan hidupnya. Rasionalitas ekonomi yang dibangun oleh konsepsi homo economicus sebagaimana dikembangkan dalam ekonomi kapitalis dan sosialis berbeda dengan rasionalitas ekonomi yang dibangun oleh konsepsi homo islamicus sebagaimana dikembangkan dalam ekonomi islam.

Dalam kapitalisme, homo economicus telah diposisikan sebagai entitas ekonomi yang mengokohkan individualitas dan eksploitasi apa saja yang dianggap penting dari motif-motif dasar manusia, hasrat dan self-interest, dan untuk dapat memproduksi standar kehidupan yang lebih tinggi. Homo economicus merepresentasikan manusia rasional yang diformalkan dalam modelmodel ekomomi tertentu yang mengaktualisasikan pemuasan self-interest sebagai cara untuk meraih tujuan-tujuan ekonomi. Adapun dalam komunisme, homo economicus digambarkan sebagai hubungan antara kondisi material dan kehidupan manusia yang esensial, yakni bahwa bukan kesadaran manusia yang menentukan keberadaannya, akan tetapi sebaliknya keberadaan sosial itulah yang menentukan kesadarannya.

Banyak ekonom muslim yang tidak puas dengan konsep homo economicus sebagai modal dasar perilaku ekonomi manusia. Karena itulah, ekonom muslim pun menggantinya dengan konsepi homo islamicus sebagai model dasar perilaku ekonomi yang sesuai dengan fitrah hakiki manusia. Istilah homo islamicus mengacu kepada perilaku individu yang dibimbing oleh nilainilai Islam. Rasonalitas yang dibangun oleh konsepsi homo islamicus berpandangan bahwa segenap tindakan ekonomi tidak hanya menuruti hasrat-hasrat alamiah manusia tetapi harus didasarkan kepada kebenaran dan kebajikan. Jalan untuk mencapai rasionalitas ini tidak lain adalah mensubordinatkan motif, pikiran, orientasi, kehendak dan perilau ekonomi kepada aturan dan moralitas yang ditentukan oleh syariat Islam.
\end{abstract}

\section{Kata Kunci (Keywords)}

Rasionalitas, Aksioma, Homo Economicus, Homo Islamicus, Mashlahah, Halal dan Thayib Things

\section{A. Pendahuluan}

Setidaknya terdapat tiga kutub ekstrim sistem ekonomi yang berkembang di dunia, yaitu kapitalis, sosialis dan islam. Ketiganya memiliki pilosofi dan rasionalitas yang berbeda dalam melihat tindakan-tindakan ekonomi manusia. Dalam perspektif ekonomi kapitalis, rasionalitas menjadi basis utama bagi semua analisis ekonomi. Rasionalitas mengasumsikan bahwa setiap pelaku ekonomi memiliki pengetahuan yang lengkap sehingga produsen dan konsumen dapat memaksimalkan utilitas mereka masing-masing. Pendek kata, rasionalitas ekonomi kapitalis mengabaikan kapasitas manusia lainnya dalam melakukan pemilihan alternatif kecuali motifmotif ekonomi yang merepresentasikan self-interest. 
Rasionalitas sudah mengakar kuat sejak masa neoklasik, mazhab ekonomi inilah yang paling keras menyuarakan rasionalitas sebagai konsep fundamental teori ekonomi. Namun demikian, banyak ekonom menyangkal bahwa konsep ini dirujukkan kepada ide Adam Smith mengenai self-interest. Gagasan awal tentang rasionalitas sebenarnya bermula dari Jeremy Bentham. Menurutnya bahwa tindakan rasional manusia adalah ketika ia terdorong untuk mencari kesenangan diri dan menghindari rasa sakit. Filosofi ini tidak hanya berlaku untuk individu tetapi juga untuk masyarakat sehingga kepentingan masyarakat tidak lain hanyalah kumpulan dari kepentingan individual. Tampak di sini bahwa rasionalitas menurut Bentham berangkat dari filsafat hedonisme ${ }^{1}$.

Berbeda halnya dengan konsep rasionalitas menurut kapitalis, pelaku ekonomi yang memiliki rasionalisasi Islam menghadapi jangkauan waktu (time horizon) yang tak terbatas. Dalam pandangan Islam, kehidupan manusia terdiri dari kehidupan dunia, kehidupan kubur (kehidupan manusia setelah mati sehingga menunggu hari pembaasan) dan kehidupan abadi akibat (kehidupan kekal setelah proses pembalasan). Oleh karena itu, mashlahah yang akan diterima di hari akhir merupakan fungsi dari kehidupan di dunia atau mashlahah di dunia terkait dengan mashlahah yang diterima di akhirat. ${ }^{2}$.

Pelaku ekonomi yang memiliki perilaku rasional islami akan memaknai mashlahah dan mengupayakannya dengan pentunjuk yang diberikan oleh Alquran dan Sunnah. Dalam hal ini Islam menjelaskan bahwa mashlahah adalah segala bentuk keadaan ataupun perilaku yang mampu meningkatkan kedudukan manusia sebagai makhluk yang paling mulia. Terdapat lima mashlahah mendasar yang diperlukan oleh manusia, yaitu mashlahah fisik, mashlahah agama, mashlahah intelektual, mashlahah antargenerasi dan waktu, dan mashlahah materi/kekayaan ${ }^{3}$. Setiap pelaku ekonomi Islam yang rasional akan berusaha meningkatkan kelima mashlahah tersebut agar tujuan jangka panjangnya yakni falah dapat terwujud.

Berdasarkan deskripsi di atas jelas bahwa konsep rasionalitas islam berbeda dengan rasionalitas menurut kapitalis. Rasionalitas dalam perspektif ekonomi kapitalis dibangun oleh konsepsi manusia sebagai homo economicus sedangkan rasionalitas dalam ekonomi islam dibangun oleh konsepsi manusia sebagai homo islamicus. Tulisan ini akan mendeskripsikan lebih lanjut tentang teori rasionalitas, khususnya dalam pandangan ekonomi Islam.

\section{B. Pembahasan}

\section{Hakikat Rasionalitas}

\footnotetext{
1 Arif Hoetomo. Ekonomi Islam: Pengantar Analisis Kesejarahan dan Metodologi (Malang: BPFE UNIBRAW, 2007) hal 230

2 Pusat Pengkajian dan Pengembangan Ekonomi Islam (P3EI) UII dan BI. Ekonomi Islam (Jakarta: Rajagrafindo Persada, 2012) hal 31

${ }^{3}$ Ibid, 32
} 
Menurut M. Nur Rianto Al Arif dan Euis Amalia bahwa rasionalitas menjadi membingungkan ketika dapat berarti banyak, seperti tidak memihak (dispassionate), beralasan (reasonable), logis (logical), dan mempunyai maksud tertentu (purposeful). Perbedaan makna tentang rasionalitas tersebut terjadi antarsesama ilmuan sosial, dimana rasionalitas menjadi topik yang kontroversi dan tidak ada definisi yan jelas, lugas, serta gamblang yang bisa diterima secara umum oleh semua pihak ${ }^{4}$. Rasionalitas mungkin akan memiliki maksud dan arti yang beda pada setiap orang. Seorang individu membuat keputusan yang menurut dia rasional, sedangkan menurut orang lain itu tidak rasional. Selain itu, sering kali terjadi perbedaan yang membingungkan antara rasionalitas menurut fakta dan teori.

Adapun Adiwarman A. Karim mengungkapkan bahwa yang dimaksud dengan asumsi rasionalitas adalah anggapan bahwa manusia berperilaku secara rasional (masuk akal), dan tidak akan secara sengaja membuat keputusan yang akan menjadikan mereka lebih buruk. Perilaku rasional dapat mempunyai dua makna yaitu metode dan hasil. Dalam makna metode, perilaku rasional berarti "action selected on the basis of reasoned thought racher than out of habbit, prejudice or emotion (tindakan yang dipilih berdasarkan pikiran yang beralasan, bukan berdasarkan kebiasaan, prasangka, atau emosi).” Sedangkan dalam makna hasil, perilaku rasional berarti "action that actually secceeds in achieving desired goals (tindakan yang benar-benar dapat mencapai tujuan yang ingin dicapai)."5

Adapun menurut P3EI UII dan BI bahwa secara umum, rasionalitas seringkali diasumsikan dalam pengambilan keputusan ekonomi, setiap pelaku selalu berpikir, bertindak dan bersikap secara rasional. Misalnya, keputusan seseorang untuk memilih salah satu dari barang sejenis yang lebih murah harganya didasarkan pada pertimbangan rasionalitas bahwa dengan tindakan ini maka kesejahteraannya akan meningkat dan ia tidak akan peduli dengan kesejahteraan penyedia barang. Demikian pula pada aktivitas ekonomi lainnya, pertimbangan rasionalitas ini sangat dominan digunakan dalam analisis ${ }^{6}$.

Argumentasi apapun yang dibangun selama hal tersebut memenuhi kaidah-kaidah logika yang ada, dan oleh karenanya dapat diterima akal, maka hal ini dapat dianggap sebagai bagian dari ekspresi rasionalitas. Oleh karena itu, terminologi rasionalitas dibangun atas dasar kaidah-kaidah yang diterima secara universal dan tidak perlu dilakukan pengujian untuk

${ }^{4}$ M. Nur Rianto Al Arif dan Euis Amalia. Teori Mikroekonomi: Suatu Perbandingan Ekonomi Islam dan Ekonomi Konvensional (Jakarta:Kencana, 2010) hal 66-69

${ }^{5}$ Adiwarman A. Karim. Ekonomi Mikro Islam (Jakarta: Rajawali Press, 2011) hal 51

${ }^{6}$ Pusat Pengkajian dan Pengembangan Ekonomi Islam (P3EI) UII dan BI, hal 27 
membuktikan kebenarannya yang disebut sebagai aksioma. Aksioma-aksioma ini akan diposisikan sebagai acuan dalam pengujian rasionalitas dari suatu argumen atau perilaku.

Dalam banyak hal, aksioma digali dari nilai-nilai dari suatu budaya yang bersifat universal. Namun, penafsiran operasional dari nilai-nilai tersebut didasarkan pada cara pandang dan berpikir yang ada pada budaya tersebut, seringkali dipengaruhi juga oleh situasi dan kondisi yang melingkupinya. Hal ini seperti yang dikatakan oleh Weber sebagaimana dikutip oleh P3EI UII dan BI bahwa rasionalitas merupakan konsepsi kultural, artinya bersifat unik untuk setiap kultur.

Syed Omar Syed Agil sebagimana dikutip oleh Menurut M. Nur Rianto Al Arif dan Euis Amalia bahwa seorang pelaku ekonomi diasumsikan rasional berdasarkan hal-hal pertimbangan-pertimbangan berikut ${ }^{7}$ :

1) Setiap orang tau apa yang mereka mau dan inginkan, serta mau mengambil suatu keputusan atas suatu hal, dari suatu yang paling diinginkan (most preferred) sampai dengan yang paling kurang diinginkan (less preferred). Serta setiap individu akan mampu bertindak dan mengambil keputusan secara konsisten.

2) Keputusan yang diambil berdasarkan pertimbangan tradisi, nilai-nilai, dan mempunyai alasan dan argumentasi yang jelas dan lugas. Hal ini menunjukkan bahwa metedologi rasionalitas ialah ketika hal ini diambil berdasarkan cara berpikir dari setiap pelaku ekonomi itu sendiri.

3) Setiap keputusan yang diambil oleh individu ini harus menuju pada pengkuantifikasian keputusan akhir dalam satuan unit moneter. Pengkuantifikasian ini akan membawa pada perhitungan dan bertendensi untuk memaksimalkan tujuan dari setiap aktivitas, di mana suatu hal yang lebih baik lebih disukai daripada yang kurang baik.

4) Dalam model produksi dan kapitalisme, rasionalitas berarti kepuasan yang dapat dicapai dengan prinsip efisiensi dan tujuan dari ekonomi itu sendiri. Disana tidak ada ruang bagi sentimen pribadi atau nilai tradisional yang tidak dapat dikuantitatifkan dalam unit moneter.

5) Perilaku seorang individu yang rasional mencapai kepuasan berdasarkan kepentingan sendiri bersifat material (materiil self-interest) akan menuntun pada pembuatan barangbarang sosial yang berguna bagi kemaslahatan umat.

6) Pilihan seseorang dapat dikatakan rasional jika pilihan ini secara keseluruhan bisa dijelaskan oleh syarat-syarat hubungan konsisten pilihan yang lebih disukai dengan definisi penampakan pilihan yang lebih disukai. Yaitu jika seluruh pilihan ini bisa dijelaskan ketika memilih yang alternatif yang lebih disukai dengan berdasarkan hubungan postulat pilihan yang lebih disukai.

${ }^{7}$ M. Nur Rianto Al Arif dan Euis Amalia, hal 67 


\section{Prinsip-Prinsip dan Jenis-Jenis Rasionalitas}

Robert S Pyndick dan Daniel L Rubinfeld sebagaimana dikutip oleh M. Nur Rianto Al Arif dan Euis Amalia bahwa prinsip-prinsip rasionalitas ekonomi adalah sebagai berikut ${ }^{8}$ :

\section{a. Kelengkapan (Completeness)}

Prinsip ini mengatakan bahwa setiap individu selalu dapat menentukan keadaan mana yang lebih disukainya di antara dua keadaan. Bila A dan B merupakan dua keadaan yang berbeda, maka individu selalu dapat menentukan secara tepat satu di antara kemungkinan berikut:

- A lebih disukai daripada B.

- B lebih disukai daripada A.

- A dan B sama-sama disukai.

- A dan B sama-sama tidak disukai.

Sebagai contoh, seorang individu hendak membeli mobil merek Honda dan Toyota, maka pilihlah yang mungkin dilakukan yaitu:

- Mobil merek Honda lebih disukai daripada Toyota.

- Mobil merek Toyota lebih disukai daripada Honda.

- Mobil merek Honda dan Toyota sama-sama disukai.

- Kedua merek mobil sama-sama tidak disukai.

\section{b. Transitivitas (Transitivity)}

Prinsip ini menerangkan mengenai konsistensi seseorang dalam menentukan dan memutuskan pilihannya bila dihadapkan oleh beberapa alternatif pilihan produk. Di mana jika seorang individu mengatakan bahwa "produk A lebih disukai dari pada produk B", dan "produk B lebih disukai daripada produk C", maka ia pasti akan mengatakan bahwa “produk A lebih disukai dari pada produk C”. Prinsip ini sebenarnya untuk memastikan adanya konsistensi internal di dalam diri individu dalam hal pengambilan keputusan.

Hal ini menunjukkan bahwa pada setiap alternatif pilihan seorang individu akan selalu konsisten dalam memutuskan preferensinya atas suatu produk dibandingkan dengan produk lain. Sebagai contoh, seorang individu hendak membeli mobil antara merek Honda, Toyota, dan Suzuki. Apabila dihadapkan antara dua pilihan antara Toyota dan Suzuki, dan ia lebih menyukai Toyota daripada Suzuki; maka bila dihadapkan pada pilihan Honda dan Suzuki, ia pasti akan menyukai Honda. Hal ini menunjukkan konsistensi dan melakukan pilihan oleh konsumen. Secara sederhana dapat dituliskan sebagai berikut:

- Honda lebih disukai aripada Toyota

${ }^{8}$ Ibid, hal 70-73 
- Toyota lebih disukai daripada Suzuki

- Honda akan lebih disukai daripada Suzuki

\section{c. Kesinambungan (Continuity)}

Prinsip ini menjelaskan bahwa jika seorang individu mengatakan "produk A lebih disukai daripada Produk B", maka setiap keadaan yang mndekati produk A pasti akan lebih disukai daripada produk B. Sebagai contoh, di mana seorang individu lebih menyukai mobil dengan merek Honda daripada merek Suzuki, maka setiap tipe model dari mobil merek Honda apa pun akan jauh lebih disukai daripada tipe model apa pun dari mobil merek Suzuki.

\section{d. Lebih Banyak Selalu Lebih Baik (The More is Always the Better)}

Prinsip ini menjelaskan bahwa jumlah kepuasan akan meningkat, jika individu mengkonsumsi lebih banyak barang atau produk tersebut. Hal ini bisa dijelaskan dengan kurva kepuasan konsumen dalam ilmu ekonomi hal ini dikenal dengan kurva indiferen (indiference curve) yang semakin meningkat akan memberikan kepuasan yang lebih baik. sehingga konsumen cenderung akan selalu menambah konsumsinya demi kepuasan yang akan didapat. Meskipun dalam peningkatan kurva indiferen ini akan dibatasi oleh keterbatasan anggaran (budget constraint).

Selain prinsip-prinsip rasionalitas di atas, M. Nur Rianto Al Arif dan Euis Amalia menambahkan prinsip-prinsip rasionalitas dalam ekonomi islam sebagai berikut:

1. Objek yang halal dan thayib (halal dan thayib things)

Dalam Islam individu dibatasi oleh aturan-aturan syariat, di mana ada beberapa barang yang tidak boleh dikonsumsi karena ada satu alasan tertentu, barang ini hukumnya haram. Sehingga konsumen muslim hanya boleh mengkonsumsi barang atau objek yang halal, baik produknya maupun prosesnya. Oleh karenanya, hanya produk-produk yang halal dan thayib (yang mendatangkan kebaikan) yang bisa dikonsumsi oleh seorang konsumen muslim dalam aktivitasnya sehari-hari. Mengapa barang thayib harus dimasukkan, sebab bisa saja ada produk-produk yang sifat produknya halal, namun tidak thayib apabila dikonsumsi. Sebagai contoh: mengkonsumsi rokok sifatnya tidak haram namun tidak thaib sebab manfaat yang didapat lebih sedikit dibandingkan dengan dampak atau akibat tidak baik yang akan diterima.

2. Lebih banyak tidak selalu lebih baik (the more the more isn't always beeter) Prinsipp ini mengkritik prinnsip keempat, di mana sesuatu yang lebih banyak tidak selamanya selalu baik. Hal ini terjadi pada barang-barang yang dapat menimbulkan 
kemafsadatan dan kemudaratan bagi individu yang mengkonsumsinya. Bila produkproduk ini dikonsumsi semakin banyak justru akan menyebabkan individu dan masyarakat menjadi lebih buruk kondisinya. Misalkan, konsumsi atas alkohol baik sedikit atau banyak tidak akan mampu memberikan kepuasan (utility) yang lebih baik, bahkan akan menimbulkan disutility. Atau misalkan seorang konsumen yang mengkonsumsi daging kambing yang notabennya halal dan thaib apabila dikonsumsi secara berlebihan (terlalu banyak) akan mendatangkan kemudaratan bagi yang mengkonsumsinya, karena dapat menimbulkan penyakit seperti kolestrol dan asam urat ${ }^{9}$.

Adapun terkait dengan jenis rasionalitas, Adiwarman A. Karim menyebutkan terdapat dua jenis rasionalitas sebagai berikut:

\section{a. Self Interest Rationality (Rasionalitas Kepentingan Pribadi)}

Prinsip pertama dalam ilmu ekonomi menurut Edgeworth adalah bahwa setiap pihak digerakan hanya oleh self interest. Hal ini mungkin saja benar pada masa-masa Edgeworth, tetapi salah satu pencapaian dari teori utilitas modern adalah pembebasan ilmu ekonomi dari prinsip pertama yang meragukan tersebut. Self interest tidak harus selalu berarti memperbanyak kekayaan seseorang dalam satuan rupiah tertentu. Kita berasumsi bahwa individu mengejar berbagai tujuan, bukan hannya memperbanyak kekayaan secara moneter. Dengan demikian, self interest sekurang-kurangnya mencakup tujuan-tujuan yang berhubungan dengan prestise, persahabatan, cinta, kekuasaan, menolong sesama, penciptaan karya seni, dan banyak lagi.

\section{b. Present-Aim Rationality (Rasionalitas Kepentingan Kolektif)}

Teori ultilitas modern yang aksiomatis tidak berasumsi bahwa manusia bersikap mementingkan kepentingan pribadinya (self interested). Teori ini hanya berasumsi bahwa manusia menyesuaikan preferensinya dengan sejumlah aksioma, secara kasarnya preferensi-preferensi tersebut harus konsisten. Individu-individu menyesuaikan dirinya dengan aksioma-aksioma ini tanpa harus menjadi self interested ${ }^{10}$.

Masalahnya adalah apakah setiap pelaku ekonomi di pasar selalu bersikap rasional? Jika dilihat bahwa rasionalitas ternyata tidak selalu mendasari perilaku ekonomi, ada kemungkinan partisipan dalam pasar mengabaikan hukum permintaan dan penawaran yang mengatur mekanisme pasar. Jika seorang konsumen yakin bahwa kenaikan harga buah apel berakibat semakin naiknya harga apel dikemudian hari, yakni konsumen

${ }^{9} \mathrm{Ibid}$, hal 70-75

${ }^{10}$ Adiwarman A. Karim, hal 51-53 
tersebut barangkali justru membeli lebih banyak apel. Ini artinya kenaikan harga apel diikuti oleh permintaan yang lebih tinggi. Dalam kasus ini, ketika pembeli aktual diwakili oleh kurva permintaan yang berkemiringan positif, perilaku self-interest oleh pembelipembeli yang prustasi di saat ada exses demand akan menyebabkan naiknya harga yang lebih tinggi daripada harga keseimbangan. Analogi yang sama juga dapat diberikan untuk penjual yang bertindak tidak rasional sehingga si penjual akan menyalahi hukum penawaran.

\section{E. Konsep Rasionalitas dalam Perspektif Ekonomi Islam}

Rasionalitas Islam secara umum dibangun atas dasar aksioma-aksioma yang diderivasikan dari agama Islam. Meskipun demikian, beberapa aksioma ini merupakan kaidah yang berlaku umum dan universal sesuai dengan universalitas agama Islam. Secara garis besar, Pusat Pengkajian dan Pengembangan Ekonomi Islam (P3EI) UII dan Bank Indoensia (BI) mengungkapkan terdapat beberapa aksioma yang membangun konsep rasionalitas ekonomi islam sebagai berikut ${ }^{11}$ :

\section{Setiap Pelaku Ekonomi Bertujuan untuk Mendapatkan Mashlahah}

Untuk mewujudkan kesejahteraan falah maka kegiatan ekonomi harus diarahkan untuk mencukupi kebutuhan guna menghasilkan mashlahah. Oleh karenanya, pada dasarnya setiap pelaku ekonomi akan berorientasi untuk mencapai mashlahah ini. Berkaitan dengan perilaku mencari mashlahah ini, seseorang akan selalu:

1) Mashlahah yang lebih besar lebih disukai daripada yang lebih sedikit.

Mashlahah yang lebih tinggi jumlah atau tingkatannya lebih disukai daripada mashlahah yang lebih rendah jumlah atau tingkatannya atau monotonicity mashlahah yang lebih besar akan memberikan kebahagiaan yang lebih tinggi, karenanya lebih disukai daripada mashlahah yang lebih kecil.

2) Mashlahah diupayakan terus meningkat sepanjang waktu.

Konsep ini sering disebut dengan quasi concavity, yaitu situasi mashlahah yang menunjukkan pola non-decreasing. Karena jika seseorang menderita sakit maka ia akan berusaha mengobati sakitnya tersebut, sebab sakit tidaklah menyenangkan dan dapat menurunkan mashlahah hidupnya. Selanjutnya dia bersedia mengeluarkan sejumlah pengobatan tertentu misalnya olahraga, vaksinasi, dan lain-lain agar tidak jatuh sakit lagi

\footnotetext{
${ }^{11}$ Pusat Pengkajian dan Pengembangan Ekonomi Islam (P3EI) UII dan BI. hal 28-31
} 
dan lebih sehat di masa depan agar mashlahah hidupnya semakin meningkat atau setidaknya tetap.

2. Setiap Pelaku Ekonomi Selalu Berusaha untuk Tidak Melakukan Kemubaziran (nonwasting)

Dapat dipahami bahwa untuk mencapai suatu tujuan, maka diperlukan suatu pengorbanan. Namun, jika pengorbanan tersebut lebih besar dari hasil yang diharapkan, maka dapat dipastikan bahwa telah terjadi pemubaziran atas suatu sumber daya. Perilaku mencegah wasting ini diinginkan oleh setap pelaku karena dengan terjadinya kemubaziran berarti telah terjadi pengurangan dari sumber daya yang dimiliki tanpa konpensasi berupa hasil yang sebanding.

\section{Setiap Pelaku Ekonomi Selalu Berusaha untuk Meminimumkan Risiko (Risk Aversion)}

Risiko adalah sesuatu yang tidak menyenangkan dan oleh karenanya menyebabkan menurunnya mashlahah yang diterima. Hal ini merupakan konsekuensi dari aksioma monotonicity dan qusi concavity. Namun, tidak semua risiko dapat dihindari atau diminimumkan. Hanya risiko yang dapat diantisipasi (anticipated risk) saja yang dapat dihindari atau diminimumkan. Ada juga risiko-risiko yang setiap orang bersedia untuk menanggungnya, karena pertimbangan mashlahah yang lebih besar. Untuk itu dalam pembahasan aksioma ini, risiko dibedakan menjadi:

1) Risiko yang bernilai (Worthed Risk)

Risiko ini mengandung dua elemen yaitu risiko (risk) dan hasil (return). Kedua istilah ini muncul karena dalam hal-hal tertentu hasil selalu terkait dengan risiko, dimana keduanya dapat sepenuhnya diantisipasi dan dikalkulasi seberapa besar peluang dan nilainya. Dengan membandingkan risiko dan hasil maka suatu risiko akan dapat ditentukan apakah risiko tersebut worthed atau tidak. Suatu risiko dapat dianggap worthed atau tidak. Suatu risiko dapat dianggap worthed jika dan hanya jika risiko yang dihadapi nilainya lebih kecil daripada hasil yang akan diperoleh.

Kemunculan fenomena worthed risk ini tidak menyimpang dari aksioma-aksioma yang dikemukakan di depan. Dalam konteks tersebut risiko dapat dianggap sebagai pengorbanan bagi seseorang yang memikulnya, sedangkan hasil dapat dianggap sebagai bagian dari mashlahah yang diterima sebagai konpensasi kesediaannya memikul risiko. Jika mashlahah yang diterima lebih besar dari risiko, yaitu engorbanan, maka pengorbanan tersebut tidak dapat dikatakan sebagai hal yang sia-sia dan karenanya tidak bertentangan dengan aksoma non-wasting. Dalam hal ini mashlahah yang positif berarti juga tidak bertentangan dengan aksioma monotonicity. 
2) Risiko yang tak bernilai (Unworthed Risk)

Meskipun worthed risk telah menjadi fenomena di banyak kegiatan ekonomi saat ini, namun terdapat pula risiko-risiko yang unworthed, yaitu ketika nilai hasil yang diharapkan lebih kecil dari risiko yang ditanggung ataupun ketika risiko dan hasil tersebut tidak dapat diantisipasi dan dikalkulasi. Objek pembahasan dalam paparan ini dibatasi pada unworthed risk. Dengan kata lain, hanya jenis risiko inilah yang setiap pelaku berusaha untuk menghindarinya.

\section{Setiap Pelaku Ekonomi Dihadapkan pada Situasi Ketidakpastian}

Ketidakpastian dapat menurunkan mashlahah yang diterima. Kemunculan risiko dalam banyak hal dapat diantisipasi melalui gejala yang ada. Gejala yang dimaksud disini adalah adanya ketidakpastian (uncertainty). Secara spesifik, situasi ketidakpastian akan dapat menimbulkan risiko. Dengan begitu suatu ketidakpastian banyak diidentikan dengan risiko itu sendiri, atau ketidakpastian dianggap sebagai dual dari resiko. Oleh karena itu, situasi ketidakpastian juga dianggap sebagai situasi yang dapat menurunkan nilai mashlahah.

\section{Setiap Pelaku Berusaha Melengkapi Informasi dalam Upaya Meminimumkan Risiko}

Dalam kondisi ketidakpastian, setiap pelaku berusaha untuk mencari dan melengkapi informasi serta kemampuannya. Hal ini kemudian digunakan untuk mengkalkulasi apakah suatu risiko masuk dalam katagori worthed atau unworthed sehingga dapat ditentukan keputusan apakah akan menghadapi risiko tersebut atau menghindarinya. Informasi ini dapat digali melalui fenomena kejadian masa lalu ataupun petunjuk/informasi yang diberikan pihak tertentu.

Lebih lanjut Pusat Pengkajian dan Pengembangan Ekonomi Islam (P3EI) UII dan Bank Indonesia menjelaskan bahwa terdapat aksioma lain yang merupakan sesuatu yang diyakini dalam Islam, antara lain ${ }^{12}$ :

\section{Adanya Kehidupan Setelah Mati}

Menurut Islam kematian bukan akhir dari kehidupan melainkan merupakan awal dari kehidupan baru. Setiap orang Islam dituntut untuk menyakini hal itu secara pasti. Kehidupan di dunia akan diakhiri dengan kematian, namun kehidupan setelah dunia, disebut akhirat, bersifat abadi. Tidak akan ada kematian setelah kehidupan di akhirat.

2. Kehidupan Akhirat Merupakan Akhir Pembalasan Atas Kehidupan di Dunia

12 Ibid. hal 30-31 
Hidup setelah mati dipercayai bukan merupakan hidup baru yang terlepas dari kehidupan di dunia melainkan kelanjutan dari hidup di dunia. Secara lebih pasti dipercayai bahwa kehidupan setelah mati merupakan masa pembalasan terhadap setiap perbuatan yang pernah dilakukan di dunia. Dengan kata lain, kehidupan di dunia merupakan ujian bagi manusia untuk mendapatkan kehidupan setelah mati.

\section{Sumber Informasi yang Sempurna Hanyalah Alquran dan Sunnah}

Pada dasarnya informasi dapat diperoleh dari fenomena kehidupan dunia masa lalu, namun kebenaran informasi ini sangat dibatasi oleh ruang dan waktu serta kemampuan pelaku dalam menginterpretasikan fenomena tersebut. Islam mengajarkan bahwa Allah telah melengkapi kelemahan manusia dengan memberikan informasi dan pentunjuk yang dapat digunakan sepanjang masa. Informasi ini dituangkan dalam bentuk kitab suci Alquran yang berisikan firman Allah serta Sunnah Nabi Muhammad Saw. Informasi ini meliputi makna, tujuan maupun proses bagaimana pelaku meningkatkan mashlahah yang diterimanya. Kedua sumber informasi ini dianggap valid tidak terbantahkan. Pelaku ekonomi hanya diperlukan untuk menginterprestasikan dan mengaplikasikannya dalam kegiatan ekonomi.

Dengan tambahan aksioma tersebut di atas, maka pelaku ekonomi yang memiliki rasionalisasi Islam menghadapi jangkauan waktu (time horizon) yang tak terbatas. Dalam pandangan Islam, kehidupan manusia terdiri dari kehidupan dunia, kehidupan kubur (kehidupan manusia setelah mati sehingga menunggu hari pembaasan) dan kehidupan abadi akibat (kehidupan kekal setelah proses pembalasan). Oleh karena itu, mashlahah yang akan diterima dihari akhir merupakan fungsi dari kehidupan di dunia atau mashlahah di dunia terkait dengan mashlahah yang diterima di akhirat. Dengan time horizon yang lebih panjang ini, maka seorang pelaku ekonomi akan merasakan ketidakpastian, terutama yang menyangkut mashlahah. Ia menghadapi situasi ketidakpastian mengenai apakah mashlahah yang akan diperolehnya di akhirat lebih baik atau lebih buruk dari yang dirasakan di dunia. Menurut aksioma quasi concavity, pelaku ekonomi Islam dipastikan akan melakukan harmonisasi mashlahah yang di terima di dunia dan di akhirat. Cara yang dilakukan sebagaimana yang dijelaskan pada aksioma quasi concavity adalah dengan mengorbankan kenikmatan di dunia ini demi kenikmatan di akhirat.

Pelaku ekonomi yang memiliki perilaku seperti di atas, selanjutnya disebut rasional Islami, yang akan memakai mashlahah dan mengupayakannya dengan pentunjuk yang diberikan oleh Alquran dan Sunnah. Dalam hal ini Islam menjelaskan bahwa mashlahah adalah segala bentuk keadaan ataupun perilaku yang mampu meningkatkan kedudukan manusia sebagai makhluk yang paling mulia. 
Terdapat lima mashlahah mendasar yang diperlukan oleh manusia, yaitu mashlahah fisik, mashlahah agama, mashlahah intelektual, mashlahah antargenerasi dan waktu, dan mashlahah materi/kekayaan. Setiap pelaku ekonomi Islam akan berusaha meningkatkan kelima mashlahah tersebut. Misalnya, perilaku pelaku ekonomi yang meninggalkan konsumsi makanan murah, namun kurang menyehatkan adalah perilaku yang rasional Islami. Demikian pula sikap pelaku ekonomi yang menghindari konsumsi dan jenis jual beli babi meskipun menguntungkan adalah tindakan rasional Islam karena tindakan ini menurunkan mashlahah agama yang lebih tinggi daripada peningkatan mashlahah fisiknya.

\section{F. Etika dan Rasionalitas Ekonomi Islam}

Kedudukan etika sangat penting dalam mengkaji konsep rasionalitas menurut dokrin ekonomi konvensional dan ekonomi islam. Aspek etika dalam ekonomi konvensional dianggap sebagai batas ekonomi karena perilaku etis dipandang sebagai perilaku tidak rasional. Tindakan etis seringkali diartikan sebagai pengorbanan kepentingan individu atau material untuk mengedepankan kepentingan sosial atau nonmaterial. Dengan demikian, ketika perilaku rasional ekonomi diartikan sebagai upaya untuk mewujudkan mashlahah materi semata, maka perilaku etis dipandang sebagai perilaku yang tidak rasional dan karenanya dikeluarkan dari pokok bahasan ilmu ekonomi.

Secara umum, moral didefinisikan sebagai standar perilaku yang dapat diterima oleh masyarakat (benar) ataukah tidak (salah). Filosofi atas suatu standar moral setiap masyarakat dapat berbeda-beda, dan alasan inilah yang dikenal dengan istilah etika. Suatu perilaku yang dianggap rasional oleh paham konvensional dapat dianggap tidak rasional dalam pandangan Islam, demikian pula sebaliknya.

Ekonomi islam mempelajari perilaku pelaku ekonomi yang rasional Islam. Oleh karena itu, standar moral suatu perilaku ekonomi didasarkan pada ajaran Islam dan bukan semata-mata didasarkan atas nilai-nilai yang dibangun oleh kesepakatan sosial. Moralitas Islam ini tidak diposisikan sebagai satu batasan ilmu ekonomi, namun justru sebagai pilar atau patokan dalam menyusun ekonomi Islam.

\section{G. Homo Economicus dan Homo Islamicus}

Menurut Arif Hoetoro bahwa dalam komunisme, homo economicus digambarkan sebagai hubungan antara kondisi material dan kehidupan manusia yang esensial, yakni bahwa bukan kesadaran manusia yang menentukan keberadaannya, akan tetapi sebaliknya keberadaan sosial itulah yang menentukan kesadarannya. Karl Mark sebagai tokoh utama 
komunisme sampai pada kesimpulan bahwa dalam masyarakat industri modern, pemilikan alat-alat produksi industri menjadi kunci utama, sebab kaum kapitalis tidak hanya menentukan tujuan ekonomi masyarakat tapi juga secara politik menguasainya serta menetapkan ukuran dan nilai-nilai sosial ${ }^{13}$.

Sedangkan dalam kapitalisme homo economicus telah diposisikan ke dalam keyakinan modern sebagai etitas ekonomi yang mengokohkan individualitas dan eksploitasi apa saja yang dianggap penting dari motif-motif dasar manusia, hasrat dan selfinterest, untuk dapat memproduksi setandar kehidupan yang lebih tinggi. Ketika hal ini menyentuh pada pemuasan dan hasrat setiap individu, betapapun hasrat itu mungkin dianggap remeh oleh orang lain, memang tidak satu sistem ekonomi yang dapat melakukannya dengan baik selain kapitalisme. Pendek kata, homo economicus merepresentasikan manusia rasional yang diformalkan dalam model-model ekomomi tertentu yang mengaktualisasikan pemuasan self-interest sebagai cara untuk meraih tujuantujuan ekonomi.

Banyak ekomom muslim yang merasa tidak puas dengan konsep homo economicus sebagai modal dasar perilaku ekonomi manusia. Menurut mereka, konsepsi ini tidak cukup menandai untuk menjelaskan dimensi manusia yang jauh lebih luas, tidak sekedar manusia yang tindakan-tindakan ekonominya diarahkan secara mekanis oleh logika ekonomi. Manusia dalam dimensinya yang luas memiliki perspektif yang menjangkau aspek-aspek material dan non material sehingga semua tindakan ekonomi-nya tidak seharusnya dibatasi oleh dimensi-dimensi material saja sebagaimana tampak dalam prilaku homo economicus. Karena itulah, ekonom Muslim pun menggantinya dengan konsepi tentang homo islamicus sebagai model dasar perilaku ekonomi yang sesuai dengan fitrah hakiki manusia.

Istilah homo islamicus mengacu kepada perilaku individu yang dibimbing oleh nilai-nilai Islam. Ekonom Muslim umumnya memakai istilah ini agar dapat mengakomodasi sifat mulia manusia baik yang mampu dilakukan oleh seorang Muslim atau tidak. Sebab harus diakui bahwa kemusliman seseorang ternyata belum menjamin kepatuhannya terhadap ajaran-ajaran Islam, atau dengan kata lain tidak setiap Musim telah berperilaku sesuai dengan ajaran-ajaran Islam. Namun tentu saja, idealnya seorang Muslim adalah homo islamicus yang sejati, atau potret diri nilai-nilai Islam yang terperaktekkan secara aktual.

${ }^{13}$ Arif Hoetomo, hal 226 


\section{Kesimpulan}

1. Asumsi rasionalitas adalah anggapan bahwa manusia berperilaku secara rasional (masuk akal), dan tidak akan secara sengaja membuat keputusan yang akan menjadikan mereka lebih buruk. Rasionalitas seringkali diasumsikan dalam pengambilan keputusan ekonomi, setiap pelaku selalu berpikir, bertindak dan bersikap secara rasional.

2. Perilaku rasional dapat mempunyai dua makna yaitu metode dan hasil. Dalam makna metode, perilaku rasional berarti "action selected on the basis of reasoned thought racher than out of habbit, prejudice or emotion (tindakan yang dipilih berdasarkan pikiran yang beralasan, bukan berdasarkan kebiasaan, prasangka, atau emosi)." Sedangkan dalam makna hasil, perilaku rasional berarti "action that actually secceeds in achieving desired goals (tindakan yang benar-benar dapat mencapai tujuan yang ingin dicapai)."

3. Terminologi rasionalitas dibangun atas dasar kaidah-kaidah yang diterima secara universal dan tidak perlu dilakukan pengujian untuk membuktikan kebenarannya yang disebut sebagai aksioma. Aksioma-aksioma ini akan diposisikan sebagai acuan dalam pengujian rasionalitas dari suatu argumen atau perilaku.

4. Prinsip-prinsip rasionalitas ekonomi konvensional meliputi: Kelengkapan (Completeness), Transitivitas (Transitivity), Kesinambungan (Continuity) dan Lebih Banyak Selalu Lebih Baik (The More is Always the Better), sedangkan prinsip-prinsip rasionalitas islam meliputi prinsip objek yang halal dan thayib (halal dan thayib things) dan lebih banyak tidak selalu lebih baik (the more the more isn't always beeter).

5. Terdapat dua jenis rasionalitas yaitu: Self Interest Rationality (Rasionalitas Kepentingan Pribadi) dan Present-Aim Rationality (Rasionalitas Kepentingan Kolektif)

6. Aksioma yang membangun konsep rasionalitas ekonomi islam sebagai berikut:
a. Setiap Pelaku Ekonomi Bertujuan untuk Mendapatkan Mashlahah
b. Setiap Pelaku Ekonomi Selalu Berusaha untuk Tidak Melakukan Kemubaziran (non- wasting)
c. Setiap Pelaku Ekonomi Selalu Berusaha untuk Meminimumkan Risiko (Risk Aversion)
d. Setiap Pelaku Ekonomi Dihadapkan pada Situasi Ketidakpastian
e. Setiap Pelaku Berusaha Melengkapi Informasi dalam Upaya Meminimumkan Risiko

7. Konsepsi homo economicus menjadi model dasar rasionalisasi perilaku ekonomi manusia dalam ekonomi konvensional sedangkan konsepsi homo islamicus sebagai model dasar perilaku ekonomi yang dibimbing oleh nilai-nilai Islam. Rasonalitas yang dibangun oleh 
konsepsi homo islamicus berpandangan bahwa segenap tindakan ekonomi tidak hanya menuruti hasrat-hasrat alamiah manusia tetapi harus didasarkan kepada kebenaran dan kebajikan. Jalan untuk mencapai rasionalitas ini tidak lain adalah mensubordinatkan motif, pikiran, orientasi, kehendak dan perilau ekonomi kepada aturan dan moralitas yang ditentukan oleh syariat Islam.

\section{Daftar Pustaka}

Azis, Abdul. 2008. Ekonomi Islam: Analiss Mikro \& Makro. Yogyakarta: Graha Ilmu.

Hoetomo Arif. 2007. Ekonomi Islam: Pengantar Analisis Kesejarahan dan Metodologi. Malang: BPFE UNIBRAW Malang

Pusat Pengkajian dan Pengembangan Ekonomi Islam (P3EI) UII dan BI. Ekonomi Islam (Jakarta: Rajagrafindo Persada, 2012) hal 31

Karim Adiwarman A. 2011. Ekonomi Mikro Islami. Jakarta: Rajagrafindo Persada

M.Nurianto AL Arif dan Euis Amalia. 2010. Teori Ekonomi Mikroekonomi: Suatu Perbandingan Ekonomi Islam dan Ekonomi Konvensional. Jakarta: Kencana 